UDK: 179.7:616.89-056.34

Izvorni naučni rad

dr. sc. Vildana Aziraj - Smajić, specijalista kliničke psihologije

Univerzitet u Bihaću

Islamski pedagoški fakultet

v.aziraj@gmail.com

\title{
PSIHOPATOLOŠKA OBILJEŽJA LIČNOSTI KOD OSOBA S PTSP-om S OBZIROM NA STATUS SUICIDALNOSTI
}

\section{Sažetak}

Rezultati dosadašnjih istraživanja sve češce ukazuju na povezanost PTSP-a i suicidalnosti, a time se u kliničkoj praksi sve više nameće značaj identificiranja suicidalnih ponaśanja u populaciji osobas PTSP-om, kao i pravovremenog preventivnog djelovanja. Bavljenje potencijalnim razlikama izmedu suicidalnih i nesuicidalnih osoba s PTSP-om s obzirom na do sada nije dalo konzistentne rezultate.

Cilj ovog istraživanja je ispitati da li u pogledu psihopatoloških obilježja ličnosti postoje razlike izmedu osoba s PTSP-om s obzirom na njihov status suicidalnosti.

$U$ istraživanje je uključeno 147 učesnika od čega 91 muškarac i 56 žena kojima je prema MKB-10 dijagnosticiran PTSP. Na osnovu statusa suicidalnosti (suicidalni/nesuicidalni) uzorak je podijeljen u dva subuzorka. Podaci su prikupljeni tokom psihološke procjene na Odjelu Neuropsibijatrije $K B$ „Dr. Irfan Ljubijankič” u Bihaću, pri čemu su primijenjeni klinički intervju, RBS i MMPI-202.

Utvrđene su značajne razlike u psihopatološkim obilježjima ličnosti između suicidalnih $i$ nesuicidalnih osoba s PTSP-om.

Konačni ishodi analiza ovih rezultata interpretirani su u smislu implikacija za intervencijske programe, te praktičnih smjernica za psihologijsku diferencijalnodijagnostičku procjenu suicidalnosti u populaciji osoba oboljelih od PTSP-a, $i$ to u nastojanju determiniranja određenih kritičnih tačaka $u$ kojima teškoće mogu eskalirati na putu od posttraumatskog stresnog poremé́aja do pokuśaja suicida $i$, na koncu, samog suicida.

Ključne riječi: suicidalnost, PTSP, psihopatološka obilježja 


\section{Uvod}

Posttraumatski stresni poremećaj (PTSP) podrazumijeva psihički poremećaj koji nastaje nakon izloženosti traumatskom događaju koji uključuje direktnu izloženost ataku na tjelesni integritet/život, kao i svjedočenje takvom događaju (APA, 2003).

$\mathrm{S}$ obzirom da je PTSP jedan od rijetkih psihijatrijskih poremećaja kojem je poznat uzrok, ovaj poremećaj u poslijeratnoj Bosni i Hercegovini predstavlja mnogo više od jedne kategorije psihičkog poremećaja, te se sve češće povezuje sa demobilisanim borcima Armije $\mathrm{BiH}$, ali i sa civilnim stanovništvom koje je preživjelo strahote rata. Upravo u ovom tranzicijskom periodu brojni aktivni učesnici rata i dalje su socioekonomski nezbrinuti i ne doživljavaju očekivanu socijalnu gratifikaciju i podršku nego naprotiv osjećaju da su na teret svojoj društvenoj zajednici što je zajedno s osjećajima bespomoćnosti, beznađa, besperspektivnosti, osjećaja gađenja prema sebi samom, sastavna odrednica suicidalnosti u ovoj vulnerabilnoj populaciji (Aziraj-Smajić, 2014; Boffa, King, Turecki i Schmidt, 2017; Brake, Rojas, Badour, Dutton i Feldner, 2017; Daniel i Goldston, 2012; Kaminski i sur, 2010.). Suicidalnost se definira kao grupa različitih ponašanja kojima je zajedničko ugrožavanje vlastitog života, a kojima je krajnji cilj izvršavanje suicida (Begić, 2011).

Rezultati brojnih dosadašnjih istraživanja uglavnom ukazuju na značajnu povezanost suicidalnosti i PTSP-a i to uz komorbitetni psihijatrijski poremećaj ili bez njega (McLean, Zang, Zandberg, Bryan, Gay, Yarvis i Foa, 2017; Nepon, Belik, Bolton i Sareen, 2010; Poindexter, Mitchell, Jahn, Smith, Hirsch, Cukrowicz, 2017). Takva povezanost se potvrđuje čak i između suicidalnosti i posttraumatskih stresnih simptoma kod osoba kod kojih nisu zadovoljeni kriteriji za utvrđivanje PTSP-a kao kompletne dijagnostičke kategorije (Boffa, Stanley, Hom, Norr, Joiner, Schmidt, 2017; Snir, Levi-Belz i Solomon, 2017). Nadalje, utvrđeno je da specifični simptomi PTSP-a mogu biti značajni prediktori suicidalnosti (Aziraj-Smajić, 2017).

Ipak, bez obzira na brojnost istraživanja u ovom području sam proces suicidalnosti osoba s PTSP-om još uvijek nije dovoljno jasan i istražen. U dostupnoj literaturi nije pronađeno niti jedno istraživanje koje se bavilo ispitivanjem kritičnih tačaka koje osobu s PTSP-om od 
nesuicidalnosti vode ka suicidalnim idejama, suicidalnim planovima, te na koncu pokušajima i samom činu oduzimanja vlastitog života svjesnom namjerom. U spomenutim istraživanjima se uglavnom koriste jednodimenzionalne skale suicidalnosti koje često nisu od koristi $\mathrm{u}$ kliničkoj procjeni suicidalnosti, s obzirom da osoba koja ima namjeru da se ubije često ne želi da se osujeti njezin plan i stoga daje socijalno poželjne odgovore koji nisu u skladu sa stvarnim psihičkim stanjem. Površnom i pogrešnom psihološkom i psihijatrijskom procjenom suicidalnosti u vulnerabilnoj populaciji osoba s PTSP-om povećava se mogućnost njihovih suicida. Pored toga, usljed povećanog broja osoba s PTSP-om koji je uzrokovan proživljavanjem ratnih traumatskih iskustava u našem regionu je zapostavljeno bavljenje istraživanjima koja uključuju osobe čiji je PTSP uzrokovan civilnom traumom.

\section{Cilj istraživanja}

Cilj ovog istraživanja je ispitati da li među osobama s posttraumatskim stresnim poremećajem postoje razlike $\mathrm{s}$ obzirom na njihov status suicidalnosti.

Specifičnost ovog pristupa u odnosu na dosadašnja istraživanja u ovom području je obuhvatanje velikog uzorka učesnika, te primjena standardiziranog psihologijskog mjernog instrumenta koji ima zadovoljavajuću pouzdanost i kojim se omogućava potpunija klinička procjena svakog učesnika, kao i prikupljanje sveobuhvatnijih podataka. Istraživanje otvara do sada nedovoljno istraživano, a u Bosni i Hercegovini potpuno nistraženo područje, te se očekuje da će svoj doprinos iskazati i kroz stvaranje literature zasnovane kako na dobivenim podacima tako i na pregledu recentnih istraživanja u ovom području.

\section{Problem istraživanja}

Ispitati postoje li neke specifičnosti u psihopatološkim obilježjima ličnosti po kojima se razlikuju osobe s PTSP-om s obzirom na suicidalni status (suicidalni - nesuicidalni) 


\section{Hipoteze}

$\mathrm{Na}$ osnovu rezultata dosadašnjih istraživanja u okviru ispitivanog područja postavljena je sljedeća hipoteza:

$\mathrm{H}$ : može se pretpostaviti da će se osobe s PTSP-om, s obzirom na status suicidalnosti, razlikovati po razini psihopatoloških obilježja na MMPI profilu.

\section{Metoda rada}

\subsection{Učesnici u istraživanju}

U ovom istraživanju učestvovalo je ukupno 147 učesnika od kojih je 91 muškarac i 56 žena. Starosne dobi su od 20 do 61 godinu. Prosječna starosna dob učesnika je 44.82 (S.D.=10.30). Ograničenjem u starosnoj dobi nastojalo se izbjeći problematičnost dijagnoze kod osoba mlađeg uzrasta, kao i eventualna deterioracija starijih osoba. U istraživanje su uključene osobe sa ratnom $(\mathrm{N}=63)$, civilnom $(\mathrm{N}=38)$ i mješovitom traumom $(\mathrm{N}=17)$. U Tabeli br. 1. prikazana je struktura uzorka prema spolu, bračnom statusu, završenoj stručnoj spremi, radnom statusu i statusu suicidalnosti.

Tabela 1: Struktura selekcioniranog uzorka prema demografskim karakteristikama i statusu suicidalnosti

Demografske varijable

Frekvencije

$\%$

Bračni status $(\mathbf{N}=118)$

Neudana/neoženjen 9

7.6

Udana/oženjen

77

65.3

Razveden/a

21

17.8

Udovac/a

11

9.3

Stručna sprema $(\mathbf{N}=118)$

Bez osnovne škole 0 0 
Osnovna škola $(\mathrm{OŠ})$

Srednja stručna sprema (SSS)

Viša i visoka stručna sprema (VŠS) i (VSS)

\section{Radni status (N=118)}

Nezaposlen/a

92

Zaposlen/a

\section{Status suicidalnosti $(\mathrm{N}=118)$}

Nesuicidalni učesnici

Suicidalni učesnici

Svi učesnici su bili hospitalizirani na Odjelu za Psihijatriju ili/i na Odjelu za interne bolesti u Kantonalnoj bolnici „Dr. Irfan Ljubijankić” u Bihaću. Svim učesnicima je prema MKB-10 dijagnosticiran anksiozni poremećaj - posttraumatski stresni poremećaj (PTSP) od strane odjeljenskih neuropsihijatara. Ostali kriteriji za odabir učesnika za istraživanje su bili: prisustvo PTSP-a uzorkovanog određenim vrstama traumatskih iskustava (ratnih, civilnih, mješovitih), odsustvo psihičkih smetnji prouzrokovanih organskom etiologijom te sposobnost davanja odgovora u pisanom obliku.

Uzorak je podijeljen na dva subuzorka i to na grupu pacijenata s PTSPom koji su pokušali suicid i grupu pacijenata s PTSP-om koji nisu pokušali suicid. Uzeti su u obzir pacijenti čija je hospitalizacija u vrijeme provođenja istraživanja uslijedila neposredno nakon pokušaja suicida ( $\mathrm{u}$ akutnom stanju), te pacijenti kod kojih je u medicinskoj povijesti bolesti evidentiran pokušaj suicida zbog kojeg su bili hospitalizirani, te oni pacijenti kojima nije evidentirana povijest suicidalnog ponašanja, a koji su upućeni na kliničku procjenu radi procjenjivanja sposobnosti za posao ili radi diferencijalno dijagnostičke kliničke obrade u druge svrhe.

U svrhu ispitivanja postojanja određenih specifičnosti $u$ psihopatološkim obilježjima ličnosti osoba s PTSP-om (s obzirom na njihov suicidalni status i na vrstu traumatskog iskustva), od ukupno 147 učesnika selekcionirano je 118 učesnika. Kriteriji za odabir ovih 
učesnika je podrazumijevao da im skor u procjeni općih intelektualnih sposobnosti pomoću RBS, bude 85 i više, te da imaju završenu osnovnu školu (da je učesnik funkcionalno pismen), budući da je time ispunjen uvjet za primjenu MMPI-a.

\subsection{Primjenjeni psihološki istrumentarij}

\subsubsection{Klinički intervju}

Ova tehnika je bila namijenjena prikupljanju podataka o bračnom, obrazovnom i radnom statusu, hereditarnoj opterećenosti obitelji, aktualnoj dijagnozi (uvid u povijest bolesti) i statusu suicidalnosti.

\subsubsection{Revidirana Beta serija (RBS; eng. Revised Beta Examination)}

Revidiranu Beta Seriju konstruirali su Kellog i Morton, 1934. godine. Novu reviziju testa izvršili su 1946. godine R.M. Lindner i M. Gurvitz. Sastoji se od šest subtestova: labirint, šifriranje, sastavljanje likova, dovršavanje slika, otkrivanje grešaka i nelogičnosti u crtežima. Daje sveobuhvatnu procjenu općih intelektualnih sposobnosti koja se može izraziti kroz kvocijent inteligencije (IQ). Relijabilnost testa iznosi 0.89.

5.3.2. Minessota multifazični upitnik ličnosti (MMPI - 202; eng. Minessota Multiphasic Personality Inventory)

Minessota multifazični upitnik ličnosti se koristi za procjenu osobina ličnosti i psihopatoloških ispoljavanja. Prvi MMPI je konstruirala grupa autora sa Sveučilišta u Minessoti (Hathway, S.R., McKinley, J.C. i sur., 1942). Od tada je MMPI doživio brojne modifikacije, a danas se kod nas uglavnom primjenjuje MMPI 201 (Biro i Berger, 1986) i MMPI 202 (Biro, 2002).

U našem istraživanju je korišten MMPI 202. Ovaj upitnik obuhvata ukupno 210 tvrdnji, pri čemu odgovori na njima mogu biti indikativni za jednu ili više od ukupno 15 skala koje čine ovaj upitnik. Prve tri skale su kontrolne i služe provjeri spremnosti učesnika za ovakvu vrstu ispitivanja: L-skala odražava rigidnost ili naivnost u pristupu testmaterijalu, sklonost prikazivanju sebe u socijalno poželjnom svijetlu. F-skala registruje konfuzno mišljenje, nerazumijevanje materijala ili samopotcjenjivanje, odnosno naglašavanje sopstvene patologije. Kskala mjeri nivo obrambenih mehanizama, odnosno, nespremnost za ispoljavanje ličnih karakteristika. Nadalje, originalno koncipirane da 
„otkrivaju“ dijagnostičke kriterije su sljedeće kliničke skale: Hs-skala (hipohondrijaze) koja se dotiče narcizma tijela i hipohondrije; D-skala (depresije) koja je namenjena otkrivanju tendenci ka hroničnoj deprimiranosti, osjećaju beskorisnosti i nespremnosti da se gleda u budućnost; Hy-skala (histerije) otkriva potiskivanje, negaciju i konverzivne simptome, kao i sklonost da se lični problemi rješavaju razvijanjem simptoma nekog organskog poremećaja; Pd-skala (psihopatske devijacije) ukazuje na nezrelost, impulsivnost, asocijalno ponašanje i manifestnu agresivnost; Pa-skala (paranoje) koja otkriva senzibilnost, hostilost i paranoidne (projektivne) obrade realnosti; Ptskala (psihastenije) otkriva anksioznost i opsesivno mišljenj; Sc-skala (shizofrenije) koja ukazuje na konfuzno i bizarno mišljenje, kao i na raskorak sa realitetom; Ma-skala (hipomanije) koja ukazuje na euforiju i hiperaktivnost. Nadalje, upitnik sadrži još četiri dodatne skale, a to su: Si-skala (skala socijalne introverzije-ekstraverzije) koja nudi važne podatke o ličnosti učesnika (nivo komunikacijskog potencijala, slika o sebi, samopoštovanje..); An-skala (anksioznosti) koja ukazuje na nivo manifestne anksioznosti; Ag-skala (agresivnosti) koja je namijenjena detekciji latentne agresivnosti; Ci-skala (lista kritičnih ajtema) koja sadrži bizarne i nedvosmisleno psihotične stavke, iz čega slijedi da je namijenjena ocjeni psihotičnosti. Ispitanik na svaku tvrdnju odgovara sa „tačno“ ili „netačno“. Za svaku skalu rezultat se izražava posebno, a s obzirom na međusobnu povezanost skala cijeli upitnik se interpretira preko konfiguracije profila. Ocjenjivanje odgovora je objektivno, prema ključu za ocjenjivanje. Opće je pravilo da se interpretiraju samo skale sa $\mathrm{T}$ skorom $\geq 70$. MMPI-202 ima dobre metrijske karakteristike (Biro, 2002). Uvjeti za njegovu primjenu su: starosna dob od 20 do 60 godina, IQ najmanje 80, te neispoljavanje/odsustvo znakova organskog oštećenja kognitivnih funkcija.

\subsubsection{Postupak istraživanja}

Istraživanje je provedeno na Odjelu za Neuropsihijatriju Kantonalne bolnice „dr. Irfan Ljubijankić“" u Bihaću, a uz odobrenje Etičkog odbora istoimene bolnice. Svaki učesnik je dao usmeni pristanak da se podaci prikupljeni u okviru redovite kliničke psihološke procjene na odjelu mogu koristiti u naučno-istraživačke svrhe. Zajamčena je povjerljivost podataka. Prikupljanje podataka se provodilo individualno u okviru redovite hospitalne obrade pacijenata na Odjelu za Neuropsihijatriju. 


\section{Rezultati}

Nakon prikupljanja i unosa rezultata u matricu podataka, uslijedila je i njihova obrada $\mathrm{u}$ skladu $\mathrm{s}$ navedenim problemima istraživanja. Za statističku obradu podataka i izračunavanje potrebnih parametara korišten je statistički paket Statistica 7.0. Prvenstveno su testirane razlike u psihopatološkim obilježjima iskazane na MMPI-202 profilu između suicidalnih i nesuicidalnih osoba s PTSP-om. Utvrđene su deskriptivne vrijednosti za svaku pojedinu kontrolnu i kliničku subskalu, kao i za dodatne subskale što se može vidjeti u Tabeli 2.

Tabela 2:Deskriptivne vrijednosti za razinu psihopatoloških obilježja na MMPI profilu kod osoba s PTSP-om s obzirom na status suicidalnosti

\section{STATUS SUICIDALNOSTI}

\begin{tabular}{lcccccc}
\hline & \multicolumn{3}{c}{ Nesuicidalni } & \multicolumn{3}{c}{ Suicidalni } \\
\hline MMPI-profil & M & SD & N & M & SD & N \\
& & & & & & \\
\hline Socijalno poželjni odgovori (L) & 46.20 & 12.80 & 45 & 55.07 & 11.45 & 73 \\
\hline Rijetki/bizarniodgovori (F) & 51.60 & 7.58 & 45 & 54.70 & 8.46 & 73 \\
\hline Odbrambeni stavprema & 49.38 & 9.39 & 45 & 43.52 & 11.58 & 73 \\
ispitivanju (K) & & & & & & \\
\hline Hipohondrijaza(Hs) & 80.38 & 10.23 & 45 & 78.25 & 17.30 & 73 \\
\hline Depresija (D) & 85.13 & 12.82 & 45 & 90.26 & 15.66 & 73 \\
\hline Histerija (Hy) & 84.33 & 13.94 & 45 & 74.49 & 14.21 & 73 \\
\hline Psihopatskedevijacije (Pd) & 64.04 & 10.44 & 45 & 75.51 & 18.98 & 73 \\
\hline Paranoja (Pa) & & & & & & \\
\hline Psihastenija(Pt) & 75.51 & 15.49 & 45 & 85.03 & 16.36 & 73 \\
\hline Shizofrenija(Sc) & 58.33 & 12.35 & 45 & 70.07 & 18.27 & 73 \\
\hline & 60.44 & 12.16 & 45 & 63.81 & 14.03 & 73 \\
\hline
\end{tabular}




\begin{tabular}{lcccccc}
\hline Hipomanija(Ma) & 47.73 & 10.65 & 45 & 35.79 & 12.16 & 73 \\
\hline Socijalnaintroverzija (Si) & 56.04 & 9.75 & 45 & 67.62 & 16.32 & 73 \\
\hline Anksioznost(An) & 67.53 & 10.91 & 45 & 71.25 & 11.66 & 73 \\
\hline Agresivnost(Ag) & 63.31 & 10.28 & 45 & 60.00 & 18.73 & 73 \\
\hline Psihotičniodgovori (Ci) & 51.98 & 7.72 & 45 & 54.00 & 9.80 & 73 \\
\hline
\end{tabular}

Iz Tabele 3. vidimo da su pokazane statistički značajne razlike u razini sve tri kontrolne skale (L, F i K) MMPI profila između suicidalnih i nesuicidalnih osoba s PTSP-om $(\mathrm{F}=(1 / 116) 16.02 ; \mathrm{p}<.05),(\mathrm{F}=(1 / 116)$ 4.04; $\mathrm{p}<.05),(\mathrm{F}=(1 / 116) 8.19 ; \mathrm{p}<.05)$. Naime, suicidalne osobe s PTSPom daju više socijalno poželjnih odgovora (L), ali i više rijetkih/bizarnih odgovora (F) na MMPI-u u poređenju s nesuicidalnim osobama s PTSP-om. Također, interesantan je podatak da nesuicidalne osobe s PTSP-om pokazuju veći odbrambeni stav prema ispitivanju (K) u poređenju sa suicidalnim osobama s PTSP-om. Međutim, značajno je da iako postoje statistički značajne razlike u razini navedenih skala, sve skale se nalaze ispod T-vrijednosti 70 što znači da su MMPI profili i kod suicidalnih i kod nesuicidalnih osoba s PTSP-om na ovom uzorku validni i interpretabilni.

Što se tiče kliničkih skala, između grupe suicidalnih i nesuicidalnih osoba s PTSP-om utvrđene su statistički značajne razlike u razini Hy $(\mathrm{F}=(1 / 116) 13.54 ; \quad \mathrm{p}<.05), \quad \mathrm{Pd} \quad(\mathrm{F}=(1 / 116) 13.80 ; \quad \mathrm{p}<.05), \quad \mathrm{Pa}$ $(\mathrm{F}=(1 / 116) 9.81 ; \quad \mathrm{p}<.05), \quad \mathrm{Pt} \quad(\mathrm{F}=(1 / 116) 14.47 ; \quad \mathrm{p}<.05) \quad$ i $\quad \mathrm{Ma}$ $(\mathrm{F}=(1 / 116) 29.45 ; \mathrm{p}<.05)$ skale. $\mathrm{U}$ vezi s tim, utvrđena je značajno veća razina skala histerije (Hy) i hipomanije $(\mathrm{Ma})$ kod nesuicidalnih osoba $\mathrm{s}$ PTSP-om. Skale psihopatske devijacije $(\mathrm{Pd})$, paranoje $(\mathrm{Pa}) \mathrm{i}$ psihastenije (Pt) su više izražene kod suicidalnih osoba s PTSP-om. Međutim, između suicidalnih i nesuicidalnih osoba s PTSP-om nisu pronađene statistički značajne razlike $\mathrm{u}$ razini skala hipohondrijaze $(\mathrm{F}=(1 / 116) .56 ; \mathrm{p}>.05)$, depresije $(\mathrm{F}=(1 / 116) 3.41 ; \mathrm{p}>.05)$ i shizofrenije $(\mathrm{F}=(1 / 116) 1.77 ; \mathrm{p}>.05)$.

Nadalje, što se tiče dodatnih kliničkih skala, između ove dvije grupe učesnika u istraživanju utvrđene su značajne razlike jedino u razini $\mathrm{Si}$ skale $(F=(1 / 116) 18.51 ; \mathrm{p}<.05)$. Naime, utvrđeno je da je skala 
introverzije (Si) više izražena kod suicidalnih osoba s PTSP-om. Statistički značajne razlike između suicidalnih i nesuicidalnih osoba $\mathrm{s}$ PTSP-om nisu pronađene $u$ razini skala anksioznosti $(F=(1 / 116) 2.96$; $\mathrm{p}>.05)$, agresivnosti $(\mathrm{F}=(1 / 116) 1.18 ; \mathrm{p}>.05)$ i psihotičnih odgovora $(F=(1 / 116) 1.39 ; p>.05)$. Iz svega navedenog jasno je da je potvrđena hipoteza kojom se pretpostavljalo da postoje značajne razlike $\mathrm{u}$ psihopatološkim obilježjima na MMPI profilu kod osoba s PTSP-om s obzirom na njihov status suicidalnosti.

Tabela 3: Sumativni prikaz jednosmjernih analiza varijance za testiranje značajnosti razlika u razini psihopatoloških obilježja na MMPI profilu kod osoba s PTSP-om s obzirom na status suicidalnosti

\begin{tabular}{lccccc}
\hline MMPI profil & SS & Df & MS & F & P \\
\hline $\begin{array}{l}\text { Socijalno poželjni } \\
\text { odgovori (L) }\end{array}$ & 2189.5 & $1 / 116$ & 2189.5 & $16.02^{*}$ & $.00^{*}$ \\
\hline $\begin{array}{l}\text { Rijetki/bizarni } \\
\text { odgovori (F) }\end{array}$ & 267.3 & $1 / 116$ & 267.3 & $4.04^{*}$ & $.05^{*}$ \\
\hline $\begin{array}{l}\text { Odbrambeni stav } \\
\text { prema ispitivanju (K) }\end{array}$ & 955.1 & $1 / 116$ & 955.1 & $8.19^{*}$ & $.01^{*}$ \\
\hline Hipohondrijaza(Hs) & 126.4 & $1 / 116$ & 126.4 & .56 & .46 \\
\hline $\begin{array}{l}\text { Depresija (D) } \\
\text { Histerija (Hy) }\end{array}$ & 731.8 & $1 / 116$ & 731.8 & 3.41 & .07 \\
\hline $\begin{array}{l}\text { Psihopatske } \\
\text { devijacije (Pd) }\end{array}$ & 2695.6 & $1 / 116$ & 2695.6 & $13.54^{*}$ & $.00^{*}$ \\
\hline Paranoja (Pa) & 3657.7 & $1 / 116$ & 3657.7 & $13.80^{*}$ & $.00^{*}$ \\
\hline Psihastenija(Pt) & 3833.8 & $1 / 116$ & 3833.8 & $14.47^{*}$ & $.00^{*}$ \\
\hline Shizofrenija(Sc) & 315.0 & $1 / 116$ & 315.0 & 1.77 & .19 \\
\hline Hipomanija(Ma) & 3968.0 & $1 / 116$ & 3968.0 & $29.45^{*}$ & $.00^{*}$ \\
\hline $\begin{array}{l}\text { Socijalna } \\
\text { introverzija (Si) }\end{array}$ & 3727.9 & $1 / 116$ & 3727.9 & $18.51^{*}$ & $.00^{*}$ \\
\hline & & & & \\
\hline
\end{tabular}




\begin{tabular}{lccccc}
\hline Anksioznost(An) & 383.8 & $1 / 116$ & 383.8 & 2.96 & .09 \\
\hline Agresivnost (Ag) & 305.2 & $1 / 116$ & 305.2 & 1.18 & .28 \\
\hline Psihotični odgovori (Ci) & 113.8 & $1 / 116$ & 113.8 & 1.39 & .24
\end{tabular}

Osim statistički značajne razlike u ispoljavanju psihopatoloških obilježja između suicidalnih i nesuicidalnih osoba s PTSP-om na Slici 1. vidimo i klinički značajnu razliku u ispoljavanju navedenih obilježja između ove dvije grupe učesnika u istraživanju. U vezi s tim, jasno je da u kliničkom smislu, nema značajne razlike između suicidalnih i nesuicidalnih osoba s PTSP-om u kontrolnim skalama MMPI upitnika. Sve tri skale u obje grupe ne prelaze T-vrijednost iznad 70, te se time cjelokupni MMPI profili ovih osoba mogu smatrati validnim za interpretaciju. Što se tiče kliničkih skala, MMPI profil suicidalnih osoba je D-Pa-Hs-Hy-Pd-Pt, dok je MMPI profil nesuicidalnih osoba D-HyHs-Pa. Od dodatnih kliničkih skala jedino je skala An klinički značajna i to u grupi suicidalnih osoba s PTSP-om.

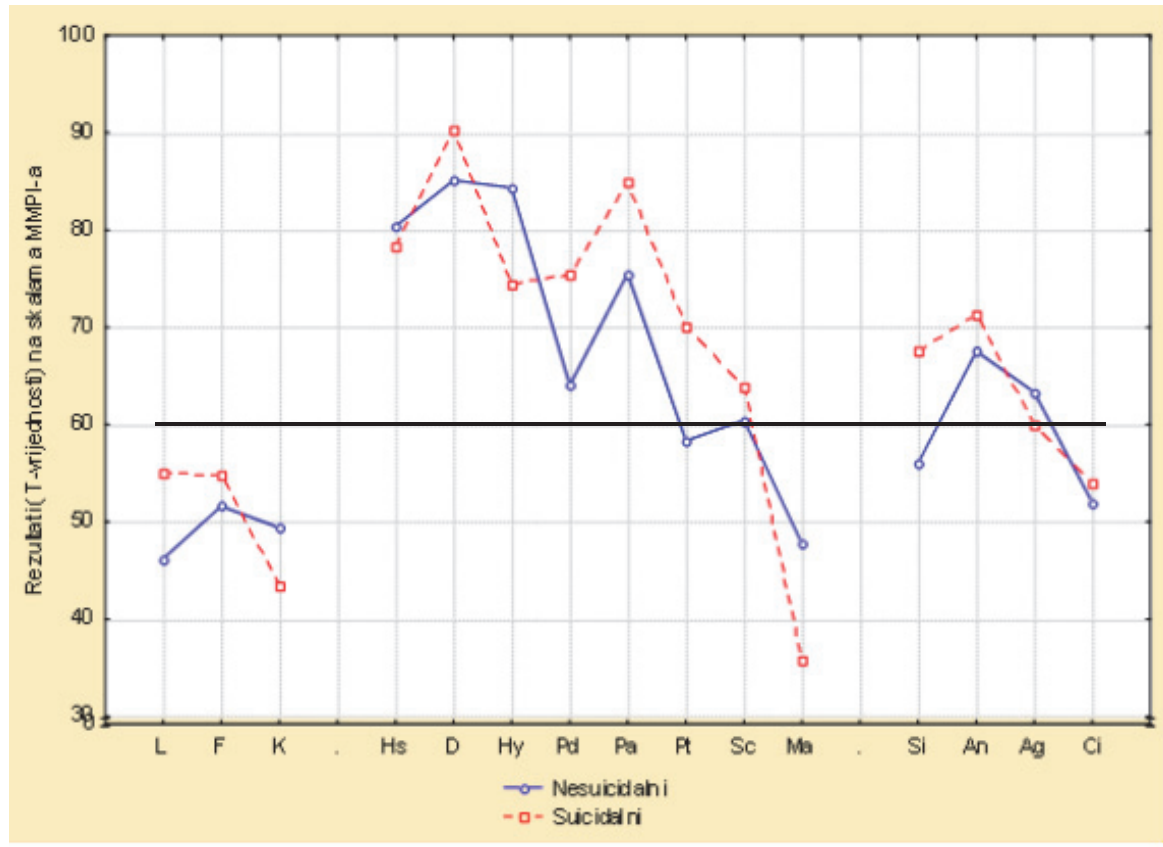

Slika 1. Grafički prikaz razine psihopatoloških obilježja na MMPI profilu kod osoba s PTSP-om s obzirom na status suicidalnosti 


\section{Diskusija}

Za otkrivanje psihopatoloških odstupanja u doživljavanju izabran je MMPI-202, jer se koristi u svakodnevnoj kliničkoj praksi i s obzirom na svoju multidimenzionalnost daje nam uvid u brojne latentne i trajnije strukture personalnog funkcioniranja osoba s PTSP-om. Dodatna prednost navedenog instrumenta jeste što ima i skale validnosti preko kojih otkrivamo da li je ispitanik u nekoj mjeri i određenom smijeru dao iskrivljenu sliku o sebi, bilo da je umanjio ili povećao ozbiljnost svojih tegoba, što je od naročitog značaja u populaciji osoba s PTSP-om s obzirom na mogućnost simuliranja ovog poremećaja.

Rezultati provedenog istraživanja pokazuju da se osobe s PTSP-om s obzirom na status suicidalnosti razlikuju po razini/izraženosti psihopatoloških obilježja na MMPI profilu. Što se tiče kliničkih skala evidentne su statistički značajne razlike u skalama histerije (Hy), paranoje $(\mathrm{Pa})$, psihastenije $(\mathrm{Pt})$ psihopatskih devijacija (Pd) i hipomanije (Ma), kao i dodatne kliničke skale - skale socijalne introverzije (Si). Dakle, osnovna razlika između suicidalnih i nesuicidalnih osoba s PTSP-om, a koja se ogleda u konfiguraciji MMPI profila, jeste da se kod suicidalnih uglavnom ukazuje na višu razinu psihotičnog ispoljavanja ( $\mathrm{Pd}, \mathrm{Pa}, \mathrm{Pt})$ dok kod nesuicidalnih ukazuje na višu razinu neurotskog psihopatološkog ispoljavanja (Hy). Može se pretpostaviti da viša razina (ali u subkliničkom prostoru) Ma skale kod nesuicidalnih osoba s PTSP-om zapravo označava veću razinu životne energije u poređenju sa suicidalnim osobama s PTSP-om i stoga je $u$ ovom slučaju ne svrstavamo u psihotične pokazatelje. Pokazane su i značajne razlike u kontrolnim skalama. U vezi s tim, kod suicidalnih osoba je pokazana veća razina L i F skale, dok je kod nesuicidalnih osoba pokazana veća razina K skale. Može se prepostaviti da ovakva razlika u konfiguraciji kontrolnih skala MMPI dijelom proizilazi iz svjesne ili nesvjesne potrebe suicidalnih osoba da prikriju stvarnu sliku sebe i svog aktualnog stanja, pogotovo kada se nađu hospitalizirani u psihijatrijskoj službi usljed akutnog pokušaja suicida (L-skala). Također, može se pretpostaviti da u takvim stanjima suicidalne osobe češće ne razumiju testovni materijal (usljed umora, konfuznosti, smetenosti i dezorijentiranosti izazvane medikacijom ili preplavljenošću aktualnom simptomatikom), te da pokazuju tendenciju davanja rijetkih/bizarnih odgovora $(\mathrm{F})$. S druge strane, značajno niža 
razina odbrambenog stava pri ispitivanju (i manje negiranje aktualnih problema), u poređenju s onom koja je pokazana kod nesuicidalnih, dijelom se može objasniti slabijom očuvanošću odbrambenih mehanizama kod suicidalnih osoba s PTSP-om.

Međutim, kako se radi o primjeni kliničkog instrumenta na kliničkom uzorku neizostavno je, osim statistički značajnih razlika, sagledati i analizirati klinički značajne razlike između ove dvije grupe učesnika u istraživanju. Ovdje je veoma važno i prisjetiti se da se MMPI skale koje se nalaze ispod T-vrijednosti 70 ne interpretiraju, jer to znači da se nalaze u kliničkom subprostoru te da nisu klinički značajne. U vezi s tim, kada analiziramo kontrolne skale MMPI upitnika (L, F, K) možemo zaključiti da bez obzira na to što postoje statistički značajne razlike u izraženosti kontrolnih skala između suicidalnih i nesuicidalnih osoba s PTSP-om, u kliničkom smislu nema značajnih razlika između ove dvije grupe učesnika. Općenito, u našem uzorku, osobe s PTSP-om nisu pokazale sklonost da se predstavljaju u socijalno poželjnijem svijetlu, psihološki prilagođenijima sa izuzetno moralnim karakternim karakteristikama (L), zatim sklonost da pretjeruju u navođenju svojih tegoba i psihološke neadaptibilnosti (F), te odbrambeni način odgovaranja i pretjeranu sklonost ka negiranju problema (K). Naime, ovdje je u kliničkom smislu najznačajniji podatak taj da se sve tri navedene skale nalaze ispod T-vrijednosti 70 što govori u prilog validnosti i interpretabilnosti cjelokupnih MMPI profila obje grupe učesnika. Čini se da nam ovaj podatak može govoriti i u prilog optimalne motivacije i suradljivosti učesnika u ovom istraživanju s obzirom da se ovakvom slikom profila kontrolnih skala može zaključiti da su učesnici ozbiljno i odgovorno pristupili testiranju, da nisu pokazali tendenciju iskrivljavanja odgovora u mjeri koja bi upućivala na obezvrijeđivanje ovog ispitivanja, te da ovi MMPI profili predstavljaju neiskrivljenu simptomatsku sliku koja nam može biti od koristi za cjelokupnu psihologijsku evaluaciju.

Nadalje, interesantno je da se kod suicidalnih osoba s PTSP-om čak šest kliničkih skala nalazi u kliničkom prostoru MMPI profila i to slijedećim redoslijedom: D-Pa-Hs-Hy-Pd-Pt, dok se kod nesuicidalnih osoba s PTSP-om samo četiri skale nalaze u kliničkom prostoru D-Hy-Hs-Pa. Ovaj podatak može upućivati na preplavljenost psihopatološkim obilježjima kod suicidalnih osoba s PTSP-om, tj. da se ove osobe ne 
uspijevaju u dovoljnoj mjeri distancirati od aktualnih tegoba što može doprinijeti pojavi i/ili porastu njihove suicidalnosti. Također, ono što se na prvi pogled uočava kao jasna distinkcija između ove dvije konfiguracije MMPI profila jeste to što je u profilu suicidalnih osoba prisutno više skala iz tzv. psihotičnog trenda $(\mathrm{Pa}-\mathrm{Pd}-\mathrm{Pt})$ što može doprinijeti njihovoj suicidalnosti, dok je u profilu nesuicidalnih osoba prisutna samo jedna skala iz tzv. psihotičnog trenda $(\mathrm{Pa})$ koja se $\mathrm{u}$ kombinaciji sa tzv. neurotskom trijadom (D-Hy-Hs) može tumačiti kao projektivna elaboracija realiteta usljed hipersenzibilnosti, a ne kao paranoidnost $\mathrm{u}$ sklopu psihotičnog trenda. Ipak, u dijagnostičkom procesu je veoma važno da potonje ispitamo potencijalno prisustvo psihotičnosti, jer bilo da se radi o psihotičnosti kao o izvojenom simptomu, u sklopu poremećaja ličnosti ili psihotičnom procesu, ne smijemo zanemariti rezultate dosadašnjih istraživanja koja ukazuju na značajnu ulogu interaktivnog djelovanja PTSP-a i poremećaja iz psihotičnog kruga u pojavi i/ili porastu suicidalnosti (Strauss i sur., 2006; Tarrier i sur., 2007; Tarrier i Picken, 2011). Ipak, skala kritičnih itema, odnosno skala psihotičnih odgovora (Ci) nije se pokazala klinički značajnom ni kod suicidalnih ni kod nesuicidalnih osoba $\mathrm{s}$ PTSP-om, a niti je pokazana statistički značajna razlika u razini navedene skale između ove dvije grupe učesnika $u$ istraživanju.

Nadalje, interesantna je pojava $\mathrm{Pd}$ skale $\mathrm{u}$ kliničkom prostoru suicidalnih osoba. Može se pretpostaviti da osnovne karakteristike ove skale kao što su manifestno ponašanje koje upućuje na porodične probleme, probleme s autoritetima, te probleme u ponašanju agresivne, manipulativne i impulzivne prirode idu u prilog pojavi i/ili porastu suicidalnosti kod osoba s PTSP-om. S obzirom da ova skala predstavlja indikator hostilnih $\mathrm{i}$ asocijalnih tendencija, te da $\mathrm{u}$ kombinaciji sa skalama Hs, D i Hy često čini tipičan profil za alkoholičare (Biro, 2002), može se pretpostaviti da potencijalne sklonosti konzumiranja alkohola kao i potencijalni komorbiditetni poremećaj vezan za zloupotrebu supstanci povećava njihovu suicidalnost što potvrđuju i brojna dosadašnja istraživanja (Cacciola i sur., 2009; Darke i sur., 2004; Eggleston i sur., 2009; Harned i sur., 2006; Maloney i sur., 2007). Dakle, ne smijemo zanemariti činjenicu da konfiguracija MMPI profila ovisi i o prisustvu pridruženih i preklapajućih simptoma koji se mogu javiti samostalno ili uz komorbiditetni poremećaj. Značajno povišenje Pd skale kod suicidalnih osoba u gore pomenutoj konfiguraciji MMPI 
profila može upućivati i na asocijalne tendencije i psihopatsko ponašanje u sklopu određenog poremećaja ličnosti što nas također može voditi ka daljnjem istraživanju da li se radi o komorbiditetnom poremećaju s OS II. U kliničkom smislu, ovo je veoma važno prepoznati tokom dijagnostičkog procesa s obzirom da je utvrđeno da međudjelovanje PTSP-a i komorbiditetnih poremećaja ličnosti značajno povećava suicidalnost (Harned i sur., 2010; Nepon i sur., 2010; Yen i sur., 2002; 2003; Zlotnik i sur., 2003). Ipak, karakteristično je kod ovog MMPI profila suicidalnih osoba s PTSP-om i to što se Pd skala javlja uz D skalu koje se međusobno gotovo isključuju (depresivnost - psihopatije), a još uz klinički značajno povišenje na $\mathrm{Pt}$ skali koje ukazuje na anksiozno-depresivne tendencije uz psihopatiju, situacija kliničke slike se dodatno usložnjava, te se čini da sve više upućuje na potencijalno prisustvo komorbiditetnih poremećaja. Svakako da bi ovo govorilo u prilog rezultatima dosadašnjih istraživanja prema kojima je suicidalnost vjerovatnija i veća kada se PTSP javlja u komorbiditetu s drugim psihijatrijskim poremećajima (Aziraj-Smajić, 2013).

Zanimljivo je spomenuti i podatak da kombinacije skala Pd i D mogu označavati i prisustvo disocijativnog procesa (Biro, 2002). Naime, kako se disocijacije mogu javiti i u sklopu PTSP-a i u sklopu nekog drugog komorbiditetnog poremećaja, npr. često graničnog poremećaja ličnosti, ponovno dolazimo do pretpostavke da pokazana kompleksna klinička slika manifestiranja psihopatoloških obilježja na MMPI profilu suicidalnih osoba s PTSP-om zapravo vodi ka pitanju prisustva pridruženih simptoma i pridruženih psihijatrijskih poremećaja. Osim toga, važno je spomenuti i istraživanja koja pokazuju da osobe koje su odmah nakon proživljenog traumatskog iskustva manifestirali snažne disocijativne simptome na MMPI profilu, imaju nakon šest mjeseci jače izražene simptome PTSP-a (Shalev, Peri, Canneti i Schreiber, 1996) za što je opravdano pretpostaviti da mogu doprinijeti pojavi i/ili porastu suicidalnosti.

Također, evidentno je da je depresivna simptomatika ono što uvjerljivo dominira kliničkom slikom u MMPI profilu i suicidalnih i nesuicidalnih osoba s PTSP-om, te da se i kod jedne i kod druge grupe učesnika u profilu pojavljuje prava neurotska trijada, odnosno uz skalu D prisutne su i skale Hs i Hy. Ipak, u kliničkom smislu evidentno je da je na profilu 
suicidalnih osoba $\mathrm{s}$ PTSP-om skala D viša u poređenju s razinom ove skale na profilu nesuicidalnih osoba s PTSP-om, i to štaviše da je D skala zauzima najviši šiljak na njihovom profilu. Upravo ovo može upućivati na snažniju sliku općeg negativnog stanja u kojem suicidalni pojedinci izvještavaju o pomanjkanju životnog elana, nedostatku nade u budućnost, nezadovoljstvu životom i lošem raspoloženju. Naime, pokazano je da su osobe koje inače postižu visoke rezultate na D skali depresivne, nesretne, disforične, pesimistične, usporene, sklone osjećajima krivnje i samopodcjenjivanju. Često se žale se na tjelesne tegobe, slabost, umor, pomanjkanje energije i osjećaj napetosti. Ti su pojedinci skloni brigama, neodlučnosti i nemaju samopouzdanja. Navode da se osjećaju beskorisnim i da većinu vremena ne mogu funkcionirati kako treba. Osjećaju se neprikladnima, a sjećaju se i da su u školi ili na poslu bili neuspješni. Osobe s visokim D rezultatima drugi ljudi doživljavaju kao introvertirane, stidljive, povučene, plašljive, zatvorene i osamljene. Sklone su zadržati psihološku udaljenost i izbjegavati interpersonalna približavanja. Drugi ih smatraju opreznima, konvencionalnim, kontroliranim i pasivnim. Te se osobe ne zalažu za svoja prava, a sklone su i popuštanju i interpersonalnim odnosima kako bi izbjegle konflikte (Butcher i sur., 2009). U vezi s navedenim, svakako da $\mathrm{u}$ diferencijalno-dijagnostičkom procesu ne smijemo zanemariti mogućnost pridruženih simptoma depresije u sklopu PTSPa, tj. PTSP pretežno depresivne kliničke slike, ali i mogućnost prisustva sasvim zasebnog komorbiditetnog poremećaja depresije uz PTSP o čijoj učestalosti, ali i njihovom međudjelovanju na pojavi i/ili porast suicidalnosti svjedoče i brojna dosadašnja istraživanja (Marshal i sur., 2001; Oquendo i sur., 2003; 2005; Pfeiffer i sur., 2009; Gradus i sur., 2010; Nelson i sur., 2011; Leiner i sur., 2008; Monin i sur., 2012). Također, pored ovih skala, ono što je karakteristično za konfiguracije MMPI profila i suicidalnih i nesuicidalnih osoba s PTSP-om jeste klinički značajno povišenje Pa skale. U vezi s tim, evidentno je da $\mathrm{Pa}$ skala zajedno sa D skalom zauzima dominantan šiljak na MMPI profilu suicidalnih osoba s PTSP-om što upućuje na osobe hipersenzitivno depresivne strukture, sklone paranoidnim interpretacijama, te depresivnom reagiranju u za njih stresnim situacijama. Dominantni mehanizam odbrane kod ovih osoba je projekcija koja se najčešće koristi u nastojanju prevazilaženja snažnog osjećaja inferiornosti ili insuficijencije, te se na takav način, u cilju reuspostavljanja 
samopoštovanja, krivica prenosi na drugoga (Biro, 2002). Ipak, s obzirom da se D i Pa skale ovdje javljaju u kombinaciji sa Pt i Pd skalama od velikog dijagnostičkog značaja je potonje ispitati da li se u pojedinačnom slučaju radi o pravim paranoidnim elaboracijama događaja oko sebe koje se javljaju bilo u sklopu paranoidnog poremećaja ili u sklopu određenog poremećaja iz psihotičnog kruga i koliko one ukoliko su prisutne mogu utjecati na pojavu i/ili porast suicidalnosti kod istih. Dakle, iz svega nevedenog možemo zaključiti da je veoma važno da se procesu procjene suicidalnosti kod osoba s PTSP-om redovno ispituje i kako oni „čitaju” realitet.

Naime, dosadašnja istraživanja su pokazala da je za osobe s PTSP-om visokog intenziteta karakterističan MMPI profil na kojem su izražene klinički značajne skale Pt-Sc-Pa (psihastenija -shizofrenija-paranoja) što ukazuje na tzv. psihotični trend koja upućuje na dominaciju simptoma psihotičnog reda. Za osobe s PTSP-om nižeg intenziteta karakterističan je MMPI profil na kojem su izražene klinički značajne skale D-Hy-Hs (depresija-histerija-hipohondrija) što ukazuje na tzv. neurotsku trijadu koja upućuje na to da kliničkom slikom dominiraju depresivni simptomi neurotskog reda (Begić i Jokić-Begić, 2007). Naime, osoba s MMPI profilom koji ukazuje na dominaciju neurotske trijade opisuje se kao osoba koja je razočarana u sebe, bez samopouzdanja, pesimista u odnosu na budućnost, kod koje je naglašeno prisustvo somato-vegetativnih simptoma (simptomi autonomnog nervnog sistema). U ovim slučajevima vrlo često se dešava da $u$ prvi plan izbijaju tjelesne tegobe $\mathrm{i}$ to sve do hipohondrijskih fiksacija. Ovakve osobe su frustraciono netolerantne, a u stresnim situacijama su sklone pasivizaciji i bježanju u bolest (Biro, 2002). S druge pak strane, pojedinac s MMPI profilom koji ukazuje na dominaciju psihotičnog trenda opisuje se kao jako uznemiren i u mukama, ne oklijeva priznati psihološke probleme, te ne posjeduje odbrambene mehanizme pomoću kojih bi se odbranio od anksioznosti. Obično izjavljuje da je depresivan, zabrinut, napet i nervozan. Može biti smeten i u stanju panike, pokazivati neodlučnost i slabo prosuđivanje. Pretjerano je intospektivan, sklon prepuštanju mislima i zamišljanjima. Naime, osobe s ovim profilom mogu dobiti dijagnozu anksioznog poremećaja, međutim vjerovatnost da postoji psihotični poremećaj ili poremećaj ličnosti raste s porastom rezultata na Sc skali. Međutim, čak i kad je dijagnosticirana psihoza, ljudi s ovim obrascem simptoma ne 
moraju pokazivati očite psihotične simptome. Vjerovatno će im biti potrebni lijekovi za kontrolu intenzivne anksioznosti i problema $\mathrm{u}$ misaonim procesima (Butcher i sur., 2009).

Na MMPI-2 pokazano je da ratni veterani s PTSP-om postižu više rezultate na kliničkim subskalama $\mathrm{Sc}$ - Pt (shizofrenija-psihastenija), a niže na subskali $\mathrm{Pa}$ (paranoja), te da je za osobe s PTSP-om karakteristično da im je kompletna konfiguracija kliničkog profila zajedno sa $\mathrm{F}$ skalom (rijetki/bizarni odgovori) viša na MMPI-2 u poređenju s profilom na MMPI-201 (Vračić i Štefan, 2003).

$\mathrm{U}$ provedenom istraživanju postoje određena ograničenja $u$ generalizaciji dobivenih rezultata, a koja proizilaze iz nedostataka provedenog istraživanja. Prvi skup ograničenja u ovom istraživanju odnosi se na uzorak. S tim u vezi, ovakvo istraživanje bilo bi bolje provesti na većem broju učesnika, te na učesnicima različite starosne dobi. Također, u ovom istraživanju oslonili smo se isključivo na dijagnozu PTSP-a koju su postavili ordinirajući psihijatri na osnovu provedenog intervjua, te nije uključena primjena psihodijagnostičkog instrumenta za procjenu aktualnog stanja posttraumatske simptomatike. $\mathrm{S}$ obzirom na veličinu, ali i iz svih navedenih podataka može se zaključiti da konačni uzorak ovog istraživanja ne pruža mogućnost šireg generaliziranja. Nadalje, jedno od ograničenja jeste i u tome što se neke od varijabli temelje isključivo na samoiskazu učesnika u istraživanju, a to su prvenstveno varijable koje se odnose na psihijatrijski hereditet $\mathrm{i}$ povijest suicida $\mathrm{u}$ porodici. S tim $\mathrm{u}$ vezi, bilo bi korisno imati heteroanamnestičke podatke. Također, ograničenje se odnosi i na činjenicu da u ovom istraživanju nije kontrolirana varijabla socijalne podrške, a postoje pokazatelji da socijalna podrška značajno utječe na težinu PTSP-a (njegovo ispoljavanje i intenzitet) iz čega proizilazi i jasna potreba za formiranjem široke mreže podrške oboljelom od strane njegovog okruženja (Milenković i sur., 2010). Upravo stoga moglo bi se pretpostaviti da ovaj faktor može značajno utjecati i na pojavu suicidalnosti u ovoj rizičnoj populaciji.

Usprkos ograničenjima, provedeno istraživanje je nedvosmisleno pokazalo da postoje razlike u psihopatološkim obilježjima ličnosti osoba s PTSP-om s obzirom na njihov status suicidalnosti. Prednost ovog istraživanja ogleda se u primjeni većeg broja različitih psihologijskih mjernih instrumenata koji se koriste u kliničkoj praksi i 
koji imaju zadovoljavajuće metrijske karakteristike, dok se većina istraživanja u ovom području ograničava isključivo na intervju ili na skale samoprocjene pri čemu ne postoji kontrola pri davanju socijalno poželjnih odgovora. Također, može se zaključiti da su dobiveni rezultati motivirajući s obzirom da govore u prilog toga da ima smisla istraživati razlike u kliničkim obilježjima između suicidalnih i nesuicidalnih osoba s PTSP-om kako preko ovih konstrukata tako i uvođenjem nekih novih konstrukata. Iz toga slijedi da je ovim istraživanjem ukazano i na smjernice u kojim područjima i kojim putevima je moguće unaprijediti istraživanje ovoga.

Preporuka za buduća istraživanja u okviru ovog područja jeste da se usmjere na još uvijek otvorena i nedovoljno istražena pitanja o ulozi PTSP-a u suicidalnosti na razini izvršenih suicida. Također, još uvijek su nedovoljno jasni mehanizmi interaktivnog djelovanja PTSP-a i komorbidnih psihijatrijskih poremećaja. Kada je riječ o komorbiditetu smatra se da bi bilo značajno, pored podataka o pridruženim psihijatrijskim poremećajima, $u$ istraživanje uključiti i pridružene tjelesne bolesti kao i podatke o invaliditetu. Pretpostavlja se da bi ovim podacima dobili sveobuhvatniji uvid u cjelokupno aktualno funkcioniranje učesnika $u$ istraživanju. $S$ obzirom na ograničenja transverzalnih studija slijedeća preporuka se odnosi na planiranje i provođenje longitudinalnih studija koje bi omogućile analiziranje uzročno - posljedičnih veza. Značajno bi bilo da se istraživači ne oslanjaju isključivo na psihijatrijske dijagnoze PTSP-a koje su postavili psihijatri samo na osnovu intervjua, te da se ispita aktualna posttraumatska simptomatika nekim od psihodijagnostičkih sredstava, npr. primjenom MPTSD (Mississippi Scale for Combat-related PTSD). Nadalje, pored uvođenja skala za procjenu PTSP-a preporuka je u istraživanje uključiti i neki od instrumenata za procjenu porodičnog funkcioniranja kako bi se uzeo u obzir i ovaj potencijalno rizični faktor za suicidalnost. Važno je uključivanje podataka o tome da li ta osoba ima (i koliko) djece i da ,li su ona maloljetna ili punoljetna. Značajan podatak je i koliko su djeca takve osobe ovisna ili nisu ovisna o tom pojedincu - kako bi se usmjerili i na neke protektivne faktore za suicidalnost. Također, što se tiče informacija o porodičnom sistemu, osim podataka o povijesti suicida u porodici, preporučuje se uzeti u obzir povijest suicidalnih pokušaja u porodici. U vezi s tim, osim podataka o psihijatrijskom hereditetu, preporučuje se uzeti u obzir i 
podatke o povijesti nasilja u porodici, te podataka o potencijalnim ranim visoko stresnim iskustvima koja su osobu mogla učiniti vulnerabilnom za razvoj PTSP-a, a kasnije i za pojavu suicidalnosti.

\section{Zaključak}

U skladu s rezultatima koje smo dobili provedenim istraživanjem izvodi se zaključak da se suicidalne i nesuicidalne osobe s PTSP-om razlikuju po izraženosti određenih psihopatoloških obilježja na MMPI profilu. Praktične implikacije ovog istraživanja se očituju u prijedlozima za poboljšanje odgovarajuće i pravovremene kliničke procjene suicidalnog rizika u ovoj populaciji. U skladu s tim, očekuje se da će rezultati istraživanja biti od koristi prvenstveno kliničkim psiholozima u diferencijalno-dijagnostičkim zadacima i dilemama tokom procjene suicidalnog rizika i to u detekciji kritičnih tačaka u kojima se pripadnici ove populacije mogu naći na putu od posttraumatskog stresnog poremećaja do pokušaja i samog izvršenja suicida. Opravdano je očekivati da će rezultati ovog istraživanja biti od koristi i zdravstvenim psiholozima, psihijatrima, suicidolozima, te svim profilima stručnjaka iz oblasti mentalnog zdravlja. Ukoliko se unaprijedi klinička procjena suicidalnog rizika unaprijedit će se i niz preventivnih strategija za smanjivanje stope suicida osoba sa posttraumatskim stresnim poremećajem u Bosni i Hercegovini. Dugoročnije gledano, ovi istraživački koraci omogućavaju aktivan doprinos smanjenju stope suicida ove populacije u Bosni i Hercegovini.

\section{Literatura}

1. American Psychiatry Association - APA (2003). Practice guideline for the assessment and treatment of patients with suicidal behaviors. American Journal of Psychiatry, 160, 1-60.

2. Aziraj-Smajić, V. i Kovačić, A. (2017). PTSP i suicidalnost: pregled dosadašnjih spoznaja o ulozi specifičnih simptoma PTSP-a u pojavi suicidalnog rizika. Knjiga sažetaka 5. Kongresa psihologa $\mathrm{BiH}$. Sarajevo: Društvo psihologa u Federaciji Bosne i Hercegovine.

3. Aziraj-Smajić, V. (2014). Obilježja ličnosti s obzirom na status suicidalnosti kod osoba s PTSP-om. Neobjavljena doktorska disertacija. Sarajevo: Odsjek za psihologiju Filozofskog fakulteta u Sarajevu. 
4. Aziraj-Smajić, V. (2013). Pregled istraživanja sklonosti samoubojstvu u osoba s PTSP-om. Neobjavljeni specijalistički rad. Zagreb: Odsjek za Psihologiju Filozofskog fakulteta u Zagrebu.

5. Begić, D. (2011). Suicidalnost. U: Begić, D. (ur.),Psihopatologija. (str. 391-397). Zagreb: Medicinska Naklada.

6. Begić i Jokić-Begić Begić D. i Jokić-Begić N. (2002). Violent behaviour and post-traumatic stress disorder. Current Opinion in Psychiatry, 15, 623-626.

7. Biro, M. (2002). Dijagnostička procena ličnosti MMPI-202. Beograd: Društvo psihologa Srbije.

8. Boffa, J.W., King, S.L., Turecki, G. i Schmidt, N.B. (2017). Investigating the role of hopelessness in the relationship between PTSD symptom change and suicidality. Journal of Affective Disorders, 225, 298-301.

9. Boffa, J.W., Stanley, I.H., Hom, M.A., Norr, A.M., Joiner, TE. i Schmidt, N.B. (2017). PTSD symptoms and suicidall thoughts and behaviors among firefighters. Journal of Psychiatry Research, 84, 277283.

10. Brake, C.A., Rojas, S.M., Badour, C.L., Dutton, C.E. i Feldner, M.T. (2017). Self-disgust as a potential mechanism underlying the association between PTSD and suicide risk. Journal of Anxiety Disorders, 47, 1-9.

11. Butcher, J.N., Graham, J.R., Ben-Porath, Y.S., Tellegen, A.W., Dahlstrom, W.G. i Kaemer, B. (2009). MMPI-2 Priručnik za primjenu, ocjenjivanje i interpretaciju. Revidirano izdanje s hrvatskim normama. Jastrebarsko: Naklada Slap.

12. Cacciola, J.S., Koppenhaver, J.M., Alterman, A.I. i McKay, J.R. (2009). Posttraumatic stress disorder and other psychopathology in substance abusing patients. Drug and Alcohol Dependence, 101, 2733.

13. Darke, S., Ross, J., Lynsekey, M. i Teesson M. (2004). Attempted suicide among entrants to three treatment modalities for heroin dependence in the Australian Treatment Outcome Study (ATOS). Drug and Alcohol Dependence, 73, 1-10.

14. Daniel, S.S. i Goldston, D.B. (2012). Hopelessness and Lack of Connectedness to Others as Risk Factors for Suicidal Behavior Across the Lifespan: Implications for Cognitive-Behavioral Treatment. Cognitive and Behavioral Practice, 19, 288 - 300. 
15. Eggleston, M.A., Calhoun, P.S., Svikis, D.S., Tuten, M., Chisolm, M.S. i Jones, H.E. (2009). Suicidality, aggression, and other treatment considerations among pregnant, substance dependent women with posttraumatic stress disorder. Comprehensive Psychiatry 50, 415-423.

16. Gradus, J.L., Qin, P., Lincoln, A.K., Miler, M., Lawler, E., Sorenson, H.T. i Lash, H.T. (2010). Posttraumatic Stress Disoder and Completed Suicide. American Journal of Epidemiology 171, 721-727.

17. Harned, M.S., Najavits, L.M. i Weiss, R.D. (2006). Self-Harm and Suicidal Behavior in Women with Comorbid PTSD and Substance Dependence. The American Journal of Addictions, 15, 392-395.

18. Harned, M.S., Rizvi, S.L. i Linehan, M.M. (2010). Impact of CoOccurring Posttraumatic Stress Disorder on Suicidal Women With Borderline Personality Disorder. American Journal of Psychiatry, 167, 1210-1217.

19. Kaminski, J.W., Puddy, R.W., Hall, D.M., Cashman, S.I., Crosby, A.E. i Ortega, A.G. (2010). The relative influence of different domains of social connectedness on self-directed violence in adolescence. Journal of Youth and Adolescence, 39, 460-473.

20. Leiner, A.S., Comptom, M.T., Houry, D., Kaslow, N.J. (2008). Intimate partner violence, psychological distress, and suicidality: a path model using data from African American women seeking care in an urban emergency department. Journal of Family Violence, 23, 473481.

21. Maloney, E., Degenhardt, L., Darke, S., Mattick, R. P., i Nelson, E. (2007). Suicidal behaviour and associated risk factors among opioiddependent individuals: a case control study. Addiction, 102, 19331941.

22. Marshall, R. D., Olfson, M., Hellman, F., Blanco, C., Guardino, M., i Struening, E. L. (2001). Comorbidity, impairment, and suicidality in subthreshold PTSD. AmericanJournal of Psychiatry, 158, 1467-1473.

23. McLean, C.P., Zang, Y., Zandberg, L., Bryan, C.J., Gay, N., Yarvis, J.S., i Foa, E.B. (2017). Predictors of suicidal ideation among active duty military personnel with posttraumatic stress disorder. Journal of Affective Disorders, 208, 392-398.

24. Monnin, J., Thiemarda, E., Vandela, P., Nicoliera, M., Tioa, G., Courtetd, P., Bellivierf, P., Sechtera, D. i Haffena, E. (2012).

Sociodemographic and psychopathological risk factors in repeated suicide attempts: Gender differences in a prospective study. Journal of Affective Disorders, 136, 35-43. 
25. Milenković, T., Simonović, M., Samardžić, Lj., Nikolić, G., Grbeša, G. i Stanković, M. (2010). Impact of social support on severity of posttraumatic stress disorder. Acta Medica Medinae, 49, 31 - 35.

26. Nelson, C., Cyra, K.S., Corbettb, B., Hurleyc, E., Gifforda, S., Elhaid, J.D. i Richardsona, J.D. (2011). Predictors of posttraumatic stress disorder, depression, and suicidal ideation among Canadian Forces personnel in a National Canadian Military Health Survey. Journal of Psychiatric Research, 45, 1483-1488.

27. Nepon, J., Belik, S.L., Bolton, J., Sareen, J. (2010). The Relationship Between Anxiety Disorders and Suicide Attempts: Findings from the National Epidemiological Survey on Alcohol and Related Conditions. Depression and Anxiety, 27, 791-798.

28. Oquendo, M.A., Friend, J.M., Halberstam, B. Brodsky, B.S., Burke, A.K., Grunebaum, M.F., Malone, K.M., Mann, J.J. (2003). Association of comorbid posttraumatic stress disorder and major depression with greater risk for suicidal behavior. American Journal of Psychiatry, 160, 580-582.

29. Oquendo, M., Brent, D.A., Birmaher, B., Geenhill, L., Kolko, D., Stanley, B., Zelazny, J. i sur. (2005). Posttraumatic stress disorder comorbid with major depression: factors mediating the association with suicidal behavior. American Journal of Psychiatry, 162, 560-566.

30. Pfeiffer, P.N., Ganoczy, D., Ilgen, M., Zivin, K. i Valenstein, M. (2009). Comorbid anxiety as a suicide risk factor among depressed veterans. Depression and Anxiety, 26, 752-757.

31. Poindexter, E.K., Mitchell, S.M., Jahn, D.R., Smith, P.N., Hirsch, J.K. i Cukrowicz, K.C. (2017). PTSD symptoms and suicide ideation:

Testing the conditional indirect effects of thwarted interpersonal needs and using substances to cope. Personality and Individual Differences, 77, 167-172.

32. Shalev, A.J., Peri, T., Canneti, L. i Schreiber, S. (1996). Predictors of PTSD in Injured Trauma Survivors: A Prospective Study. American Journal of Psychiatry, 153, 219-225.

33. Snir, A., Levi-Belz, J. i Solomon, Z. (2017). Is the war really over? A 20 -year longitudinal study on trajectories of suicidal ideation and posttraumatic stress symptoms folowing combat. Psychiatry Research, 247, 33-38.

34. Strauss, J.L., Calhoun, P.S., Marx, C.E., Stechuchak, K.M., Oddone, E.Z., Swartz, M.S. i Butterfield, M.I. (2006). Comorbid posttraumatic stress disorder is associated with suicidality in male veterans with 
schizophrenia or shizoaffective disorder. Schizophrenia Research, 84, 165-169.

35. Tarrier, N. i Gregg, L. (2004). Suicide risk in civilian PTSD patients. Predictors of suicide ideation, planning and attempts. Social Psychiatry and Psychiatrics Epidemiology, 39, 655 - 661.

36. Tarrier, N., Khan, S., Cater, J. i Picken, A. (2007). The subjective consequences of suffering a first episode psychosis: trauma and suicide behaviour. Social Psychiatry and Psychiatric Epidemiology 42, 29-35.

37. Tarrier, N. i Picken, A. (2011). Co-morbid PTSD and suicidality in individuals with schizophrenia and substance and alcohol abuse. Social Psychiatry and Psychiatric Epidemiology 46, 1079-1086.

38. Vračić, I. i Štefan, S. (2003). Primjena MMPI-2 u vojnopsihologijskoj dijagnostici: neki pokazatelji primjene na vojnoj populaciji $u$ psihodijagnostici PTSP, usporedba s MMPI-201. Knjiga sažetaka 11. god. konferencija hrvatskih psihologa, Petrčane.

39. Zlotnick, C., Johnson, D.M., Yen, S., Battle, C.L., Sanislow, C.A., Skodol, A.E., Grilo, C.M., McGlashan, T.H., Gunderson, J.H., Bender, D.S., Zanarini, M.C. i Shea, M.T. (2003). Clinical features and impairment in women with Borderline Personality Disorder (BPD) with Posttraumatic Stress Disorder (PTSD), BPD without PTSD, and other personality disorders with PTSD. The Journal of Nervous and Mental Disease, 191, 706-713.

40. Yen, S., Shea, M.T, Battle, C.L, Johnson, D.M, Zlotnick, C., DolanSewell, R., Skodol, A.E., Grilo, C.M., Gunderson, J.G., Sanislow, C.A., Zanarini, M.C., Bender, D.S., Rettew, J.B., McGlashan, T.H. (2002). Traumatic exposure and posttraumatic stress disorder in borderline, schizotypal, avoidant, and obsessive-compulsive personality disorders: findings from the Collaborative Longitudinal Personality Disorders Study. The Journal of Nervous and Mental Disorder, 190, 510-518. 
Original scientific article

Vildana Aziraj-Smajić, PhD, spec. of Clinical Psychology

University of Bihac

Islamic Pedagogical Faculty

v.aziraj@gmail.com

\section{PSYCHOPATHOLOGICAL CHARACTERISTICS OF PERSONALITY IN PERSONS WITH PTSD IN REGARDS TO THE STATUS OF SUICIDALITY}

\section{Abstract}

The results of previous research increasingly indicate the correlation of PTSD and suicidality, and this increasingly imposes the importance of identifying suicidal behaviors in the population of PTSD, as well as timely preventive action in a clinical practice. Addressing the potential differences between suicidal and non-suicidal people with PTSD, so far has not yielded consistent results.

The aim of this research is to examine whether there are differences in the psychopathological characteristics of a personalitywith between persons with PTSD in regard to their suicidal status.

The survey has involved 147 participants, out of which 91 men and 56 women who were diagnosed with PTSD according to $M K B-10$. Based on suicide status (suicidal / non-suicidal), the sample is divided into two subunits. The data were collected during a psychological assessment at the Department of Neuropsychiatry CH "Dr. Irfan Ljubijankic "in Bihac, with a clinical interview, RBS and MMPI-202.

There have been identified significant differences in the psychopathological characteristics of the personality between suicidal and non-suicidal persons with PTSD.

The final outcomes of the analysis of these results are interpreted in terms of implications for intervention programs and practical guidelines for the psychological differential diagnostic assessment of suicidality in the population of PTSD-affected individuals in an effort to determine certain critical points in which difficulties can escalate in the posttraumatic stress disorder until the suicide attempt, and, ultimately, the suicide itself.

Keywords: suicide, PTSD, psychopathological features 
المدرسة المسـاعدة فيلدانا آزيراي - سماييتش -أخصائية في علم النفس السريري

$$
\begin{aligned}
& \text { جامعاة بيهاتش } \\
& \text { كلية التربية الإسلامية } \\
& \text { v.aziraj@gmail.com }
\end{aligned}
$$

علامات الأمراض النفسية للشخصية لدى الأشخاص المصابين بمرض الاضطراب ما بعد الصيدمة (PTSP) من حيث درجة الميل إلى الانتحار

\section{الخلاصية}

نتائج الدراسات التي تم إجراؤها إلى الآن تشير بشكل متزايد إلى الارتباط بين المصابين

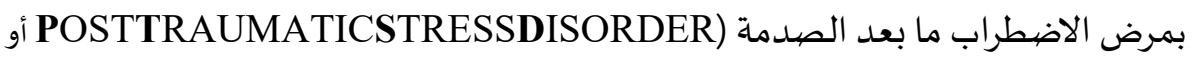
وبين الميل إلى الانتحار وبذلك في الممارسة السريرية تبرز أهمية تحديد السوكيات (PTSP

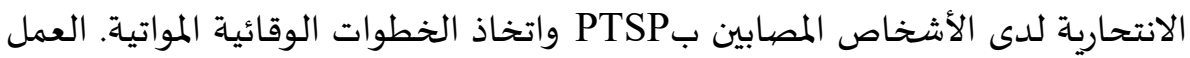

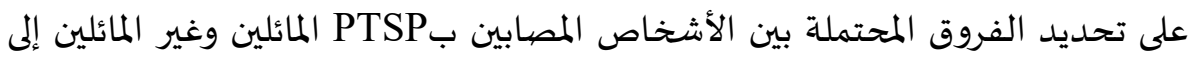
الانتحار لم تعط نتائج متناسقة.

الهدف من هذه الدراسة هوبحث تحديد، نظرًا إلى علامات الأمراض النفسية

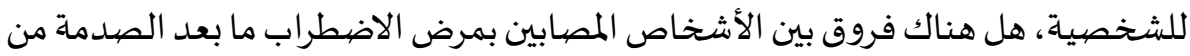
حيث درجة الميل إلى الانتحار.

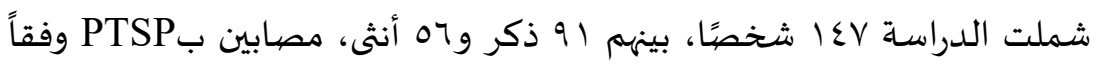
لMKB-10. بناء على الميل إلى الانتحار (المائلين وغير المائلين) فإن العينة تم توزيعها إلى الى الى مجموعتين. المعلومات تم جمعها خلال التقييم النفسي في قسم الطب النفسي لمستشفى الماءئ إقليمي "د. عرفان ليوبيانكيتش" في مدينة بيهاتش عن طريق الحوارات السريرية و وRBS .MMPI-202,

تم التأكد من وجود فروق كبيرة بين الأشخاص المصابين بPTSP المائلين وغير المائلين إلى الانتحار.

الحصائل النهائية لهذه النتائج تم عرضها نظرًا للنتائج في برامج التدخل، بالإضافة

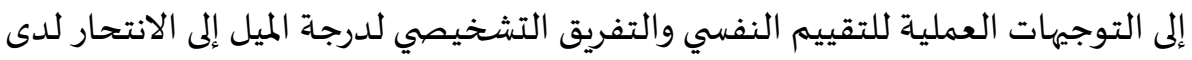
الأشخاص المصابين بPTSP بهدف تحديد بعض النقاط الحرجة حيث من الممكن 


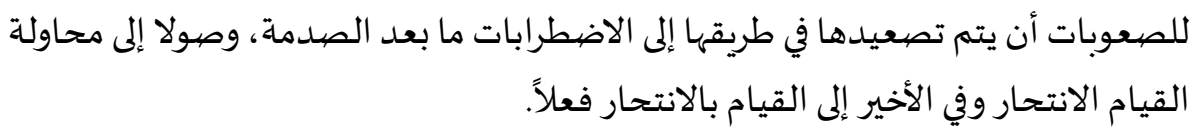

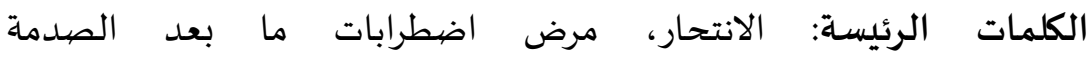
POSTTRAUMATIC STRESS DISORDER) 